\title{
Distribution of Some Elements in the Egyptian Black Sands from Abu Khashaba Beach Area
}

\author{
H. H. Mahmoud ${ }^{1}$, A. M. Abdel-Lateef ${ }^{1,2}$, A. M. Attiah ${ }^{1}$ \\ ${ }^{1}$ Central Laboratory for Elemental and Isotopic Analysis, Nuclear Research Center, Cairo, Egypt; ${ }^{2}$ Physics Department, Faculty of \\ Science and Human Studies, Shaqra University, Shaqra, KSA. \\ Email: qesat_alams@yahoo.com
}

Received October $1^{\text {st }}, 2012$; revised November $9^{\text {th }}, 2012$; accepted November $21^{\text {st }}, 2012$

\begin{abstract}
Inductively Coupled Plasma-Mass Spectrometry (ICP-MS) technique was used to determine the concentrations of titanium (Ti), vanadium (V), Chromium (Cr), Manganese (Mn), iron ( $\mathrm{Fe})$, zinc $(\mathrm{Zn})$, arsenic (As), zirconium $(\mathrm{Zr})$, cadmium (Cd) and hafnium (Hf) in black sands samples. 18 black sands samples were collected from the Mediterranean coast-Abu Khashabou Rosetta area, Egypt. Alkaline fusion procedure using mixture of Li-meta borate and tetra borate was used for the digestion of black sands samples. The average concentrations of Ti, V, Cr, Mn, Fe, Zn, As, Zr, Cd and Hf were 435.06 ppm, 322.32 ppm, 2515.03 ppm, 596.45 ppm, 185894 ppm, 249.95 ppm,309.32 ppm, 1077.26 ppm, $33.56 \mathrm{ppm}$ and $3520.32 \mathrm{ppm}$, respectively. The procedure was tested with Basalt Hawaiian Volcanic Observatory (BHVO-2) standard reference material.
\end{abstract}

Keywords: Alkaline Fusion; Black Sand; ICP-MS; Rosetta Branch

\section{Introduction}

The Egyptian black sands [1-3] are the end products of the disintegrated materials from the igneous and metamorphic rocks. The Egyptian black sand deposits comprise huge reserves of the six common economic minerals [4-6] that include ilmenite $\left(\mathrm{Fe}^{2+} \mathrm{TiO}_{3}\right)$, magnetite $\left(\mathrm{Fe}_{2}{ }^{3+} \mathrm{Fe}^{2+} \mathrm{O}_{4}\right)$, garnet $\left(\mathrm{X}_{3} \mathrm{Y}_{2} \mathrm{Si}_{3} \mathrm{O}_{12}\right.$ where $\mathrm{X}-\mathrm{Mg}, \mathrm{Fe}, \mathrm{Ca}$ and $\mathrm{Y}-\mathrm{Al}, \mathrm{Fe}, \mathrm{Cr})$, zircon $\left(\mathrm{ZrSiO}_{4}\right)$, rutile $\left(\mathrm{TiO}_{2}\right)$ and monazite $(\mathrm{Ce}, \mathrm{La}, \mathrm{Nd}, \mathrm{Th}) \mathrm{PO}_{4}$. The Rosetta black sands have been the subject of many articles $[7,8]$ and dissertations, as well as technical reports by private firms. Many of these studies and reports dealt with the mineralogy of these black sands and discussion of their economics. In this work, we discuss the elemental composition of these black sands that collected from Abu Khashaba Beach Area.

The elements selected are chosen for their importance for the probability of their environmental impact in case of their presence with higher concentrations than the normal levels. These environmental impacts may be due to their toxicity $[9,10]$ and other harmful effects associated with their higher concentrations.

For determination of the concentration of the elemental composition of the black sands samples various analytical techniques can be used such as atomic absorption spectrometry [11,12], graphite furnace atomic absorption spectrometry $[13,14]$, inductively coupled plasma atomic emission spectrometry $[15,16]$, inductively coupled plasmamass spectrometry $[17,18]$, and laser ablation-inductively coupled plasma-mass spectrometry $[19,20]$. In this study ICP-MS technique is selected to be used for determining the concentration of elemental composition of black sands samples for its high efficiency of the detection of the trace elements.

\section{Experimental Conditions}

\section{Samples}

Samples are collected from Abu Khashaba beach area, Rosetta branch (Figure 1). This location extends parallel to the Mediterranean coast. It is an open area occupied mainly by sabkha. There is no human activity because it is considered a military zone. It is nearly flat and very gently dipping (nearly horizontal) to north.

Six sampling profiles (Figure 2) denoted by symbols $A_{1}, A_{2}$ to $A_{6}$ from east to west) spaced in-between by about $600 \mathrm{~m}$ and extending into the land from the beach line for about $50 \mathrm{~m}$ or less. Along each profile, three black sand samples are collected, the first sample from the surface at the beach line (denoted by A1, A2, ....., and A6, the second sample from the end of the tidal area (the wet area by the high tide) at a depth of about $50 \mathrm{~cm}$ (denoted by $\mathrm{A} 1^{\prime}, \mathrm{A} 2^{\prime}, \cdots \cdots$, and $\left.\mathrm{A} 6^{\prime}\right)$, and the third sample 


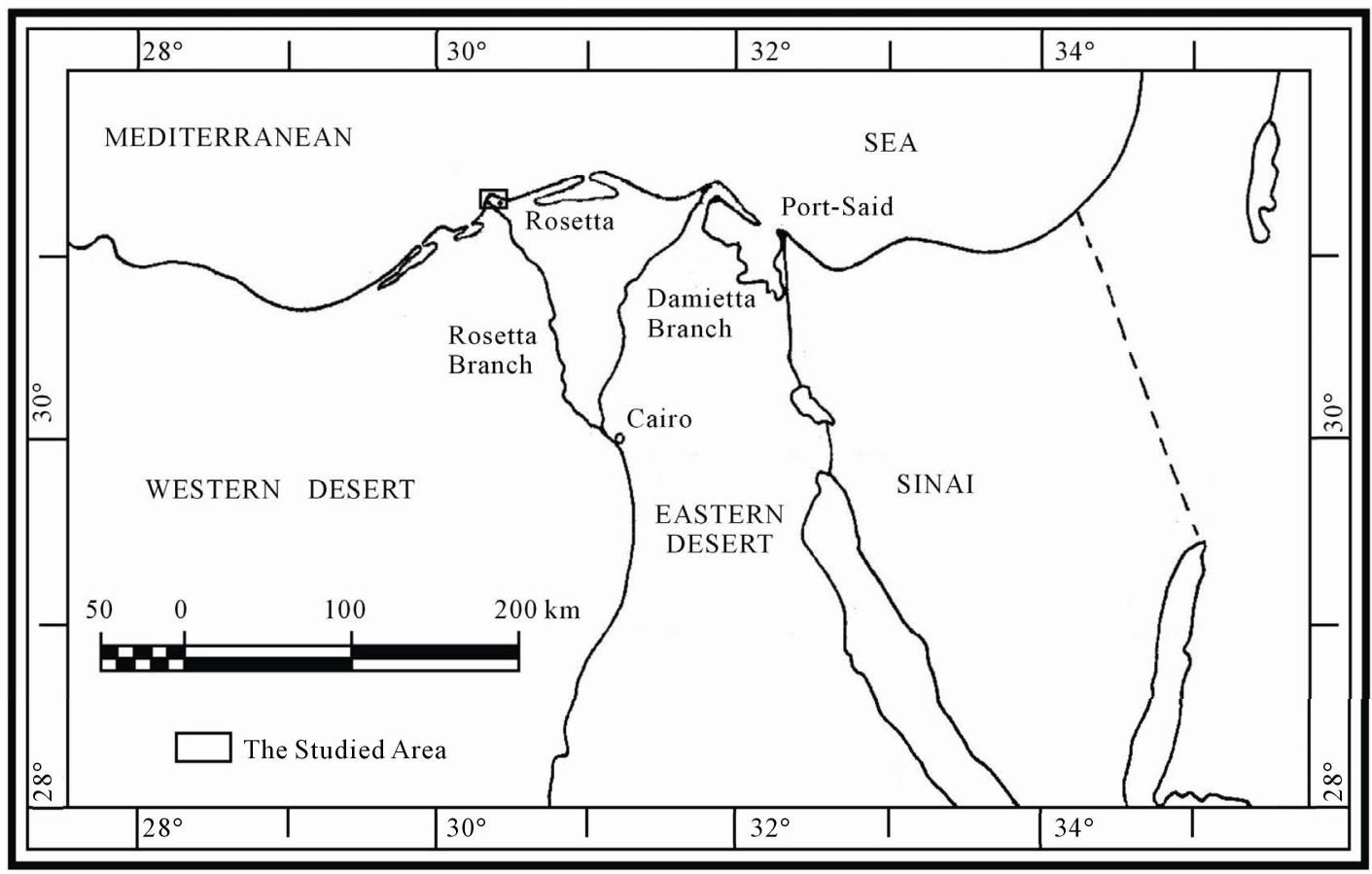

Figure 1. Location map of the studied area.

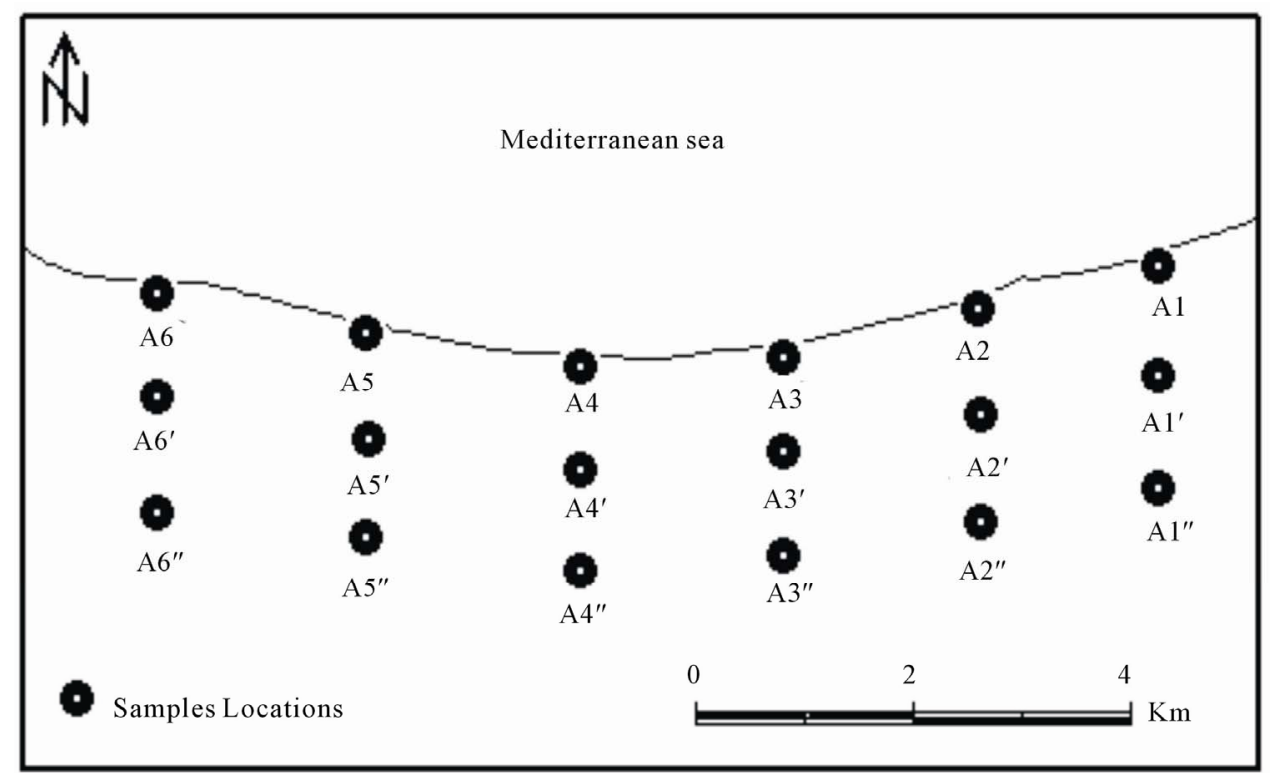

Figure 2. Map of the study area.

was taken from the dry area at a depth of about $1 \mathrm{~m}$ (denoted by A1", A2", ....., and A6").

\section{Sample Preparation}

The samples were dried in an oven at $115^{\circ} \mathrm{C}$, mechanically crushed, and sieved through a 200 mesh sieve. All samples are treated by the process of an open-vessel acid digestion. The sequential steps of the alkaline fusion procedure for digestion of black sand samples are summa- rized in Scheme 1.

\section{Reagents}

Multi elements standard solution of the studied elements was prepared of analytical grade level. All solvents and chemicals were of high purity analytical grade. Ultra pure double deionized water (18 $\Omega \mathrm{ohm}-\mathrm{cm})$ was used to dilute black sands samples and in the preparations of studied elements and reagents. 


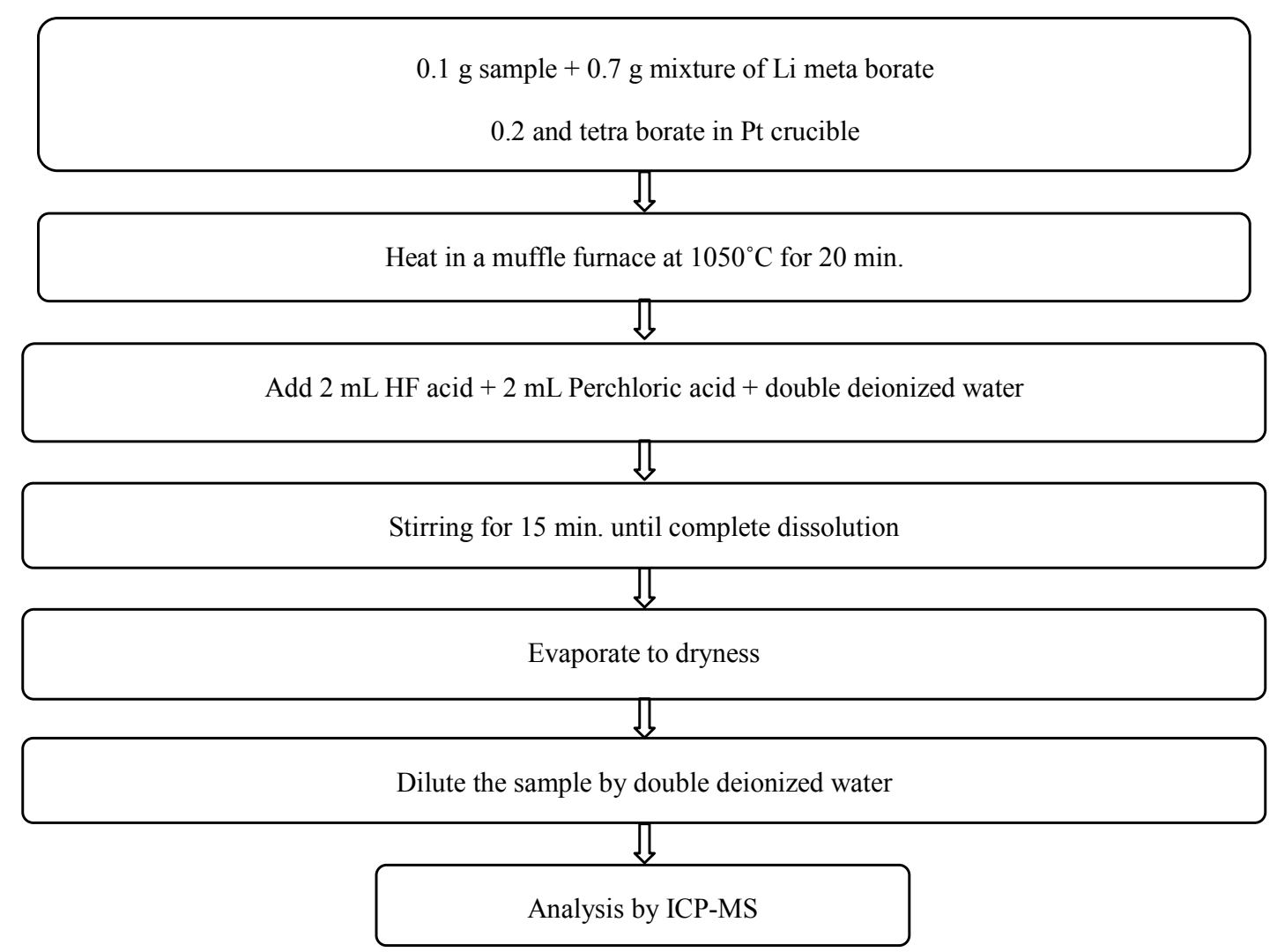

Scheme 1. Alkaline fusion procedure for digestion of black sand samples.

\section{Instrumentation}

The high resolution inductively coupled plasma-mass spectrometry (JMS-PLASMAX2) technique is used for the elemental analysis of the collected black sands samples, where the experimental conditions are shown in Table 1.

Table 1. the experimental conditions for the high resolution inductively coupled plasma-mass spectrometry (JMSPLASMAX2).

\begin{tabular}{lc}
\hline \multicolumn{2}{c}{ ICP-MS parameters } \\
\hline Forward RF power & $1300 \mathrm{watt}$ \\
Reflected RF power & $<2 \mathrm{watt}$ \\
Cooling gas flow rate & $14 \mathrm{~L} / \mathrm{min}$ \\
Auxillary gas flow rate & $0.3 \mathrm{~L} / \mathrm{min}$ \\
Nebulizer gas flow rate & $0.77 \mathrm{~L} / \mathrm{min}$ \\
Accelerating voltage & $6 \mathrm{KV}$ \\
Optimization & $89 \mathrm{Y}^{+}$ \\
Sampler cone & Maximum ion intensity of $1 \mathrm{ppb}$ of \\
Skimmer cone & Copper with $0.9 \mathrm{~mm}$ orifice \\
\hline
\end{tabular}

\section{Results and Discussion}

The validity of this method is confirmed by Basalt Hawaiian Volcanic Observatory (BHVO-2) as certified reference material. From Table 2 it is found that the obtained results and the certified reference values are close. Also the accuracy of each studied element is calculated.

Table 2. Elements concentration (ppm) of BHVO-2 by ICPMS.

\begin{tabular}{cccc}
\hline Element & Measured value & Certified value & Accuracy $(\%)$ \\
\hline $\mathrm{Ti}$ & $15853 \pm 120$ & $16300 \pm 200$ & 2.74 \\
$\mathrm{~V}$ & $328 \pm 4$ & $317 \pm 11$ & 3.47 \\
$\mathrm{Cr}$ & $265 \pm 3$ & $280 \pm 19$ & 5.36 \\
$\mathrm{Mn}$ & $1364 \pm 21$ & $1290 \pm 40$ & 5.74 \\
$\mathrm{Fe}$ & $82852 \pm 71$ & $80630 \pm 1400$ & 2.76 \\
$\mathrm{Zn}$ & $97 \pm 0.20$ & $103 \pm 6$ & 5.82 \\
$\mathrm{As}$ & $1.4 \pm 0.01$ & - & - \\
$\mathrm{Zr}$ & $182 \pm 1.40$ & $172 \pm 11$ & 5.81 \\
$\mathrm{Cd}$ & $0.3 \pm 0.01$ & - & - \\
$\mathrm{Hf}$ & $3.9 \pm 0.10$ & $4.1 \pm 0.3$ & 4.88 \\
\hline
\end{tabular}


Elemental analyses for 18 sediment samples were performed by using inductively coupled Plasma-mass spectrometer. Table 3 shows the elements concentrations for the analyzed black sand samples which collected from the Abu Khashabou beach area.

Ti ranges in concentration between $327.44 \mathrm{ppm}$ and $538.05 \mathrm{ppm}$, with an average of $435.06 \mathrm{ppm}$ in the collected sediment samples. $\mathrm{V}$ shows a general decrease in concentration from the sediment samples collected from the shore line backward into the land area behind, ranging between a minimum concentration of $268.74 \mathrm{ppm}$ and a maximum concentration of $391.94 \mathrm{ppm}$, with an average of $322.32 \mathrm{ppm}$. A general decrease in $\mathrm{Cr}$ concentration through the collected sediment samples is noticed from the shore line backward into the land area behind varying from $2178.19 \mathrm{ppm}$ to $2902.71 \mathrm{ppm}$, with an average of $2515.95 \mathrm{ppm}$. Like $\mathrm{Cr}$ and $\mathrm{V}$, Mn concentration shows a general decrease from the sediment samples collected from the shore line backward to the samples collected from the land area behind, ranging between $501.23 \mathrm{ppm}$ as a minimum amount of concentration and $610.80 \mathrm{ppm}$ as a maximum amount of concentration, with an average of $596.45 \mathrm{ppm}$. Fe shows higher concen- trations in the samples collected from the shore line area with a general decrease backward into the land area behind, ranging between 154,306 ppm and 218,425 ppm, with an average of $185,894 \mathrm{ppm}$. $\mathrm{Zn}$ ranges from 211.48 ppm to $298.50 \mathrm{ppm}$; with an average of $249.95 \mathrm{ppm}$ through the collected sediment samples; with higher concentrations recorded in the samples collected from the shore line than those of the samples collected from the land. As shows an irregular pattern where it varies in concentration from $271.65 \mathrm{ppm}$ to $352.65 \mathrm{ppm}$; with an average of $309.32 \mathrm{ppm}$ through the collected sediment samples. $\mathrm{Zr}$ shows a general decrease in concentration from the shore line backward the land area behind through the collected sediment samples, ranging between 926.27ppm and $1616.77 \mathrm{ppm}$; with an average of $1077.26 \mathrm{ppm}$. Cd shows a nearly regular distribution with a general decrease in content from the sediment samples collected from the shore line backward through the samples collected from the land area behind. It ranges between $28.21 \mathrm{ppm}$ and $39.99 \mathrm{ppm}$; with an average of $33.56 \mathrm{ppm}$. The higher concentrations of Hf are recorded in the sediment samples collected from the shore line area; it ranges between 3081.69 ppm and 4599.19 ppm;

Table 3. Elements concentrations (ppm) of the black sand samples collected from Abu Khashaba beach area by ICP-MS.

\begin{tabular}{|c|c|c|c|c|c|c|c|c|c|c|}
\hline Samples & $\mathbf{T i}$ & $\mathbf{V}$ & $\mathrm{Cr}$ & Mn & $\mathbf{F e}$ & Zn & As & $\mathrm{Zr}$ & Cd & Hf \\
\hline A1 & 432.79 & 338.93 & 2811.27 & 610.80 & 193,925 & 298.50 & 363.55 & 1185.45 & 36.97 & 4599.19 \\
\hline A1' & 428.21 & 315.15 & 2645.37 & 595.96 & 154,780 & 246.64 & 352.65 & 1043.32 & 34.35 & 3204.15 \\
\hline A1” & 327.44 & 271.71 & 2313.83 & 590.15 & 154,306 & 217.37 & 268.32 & 1011.89 & 31.97 & 3081.69 \\
\hline A2 & 538.05 & 391.94 & 2902.71 & 608.36 & 213,144 & 285.51 & 315.86 & 1616.77 & 32.81 & 3787.10 \\
\hline A2' & 492.98 & 336.29 & 2746.01 & 599.63 & 181,344 & 251.49 & 306.54 & 1039.15 & 32.17 & 3532.59 \\
\hline A2" & 431.06 & 280.69 & 2204.97 & 501.23 & 157,023 & 214.42 & 271.65 & 1039.03 & 28.21 & 3106.76 \\
\hline A3 & 446.78 & 333.65 & 2618.75 & 609.10 & 197,909 & 224.38 & 279.06 & 1069.50 & 34.45 & 3839.15 \\
\hline A3' & 431.92 & 289.67 & 2598.66 & 606.50 & 194,953 & 220.91 & 274.98 & 1041.13 & 31.27 & 3363.69 \\
\hline A3” & 429.33 & 268.74 & 2178.19 & 605.92 & 159,740 & 211.48 & 249.53 & 1042.12 & 30.28 & 3084.22 \\
\hline A4 & 447.66 & 337.76 & 2629.37 & 610.80 & 179,825 & 294.41 & 325.35 & 1086.19 & 39.10 & 3470.52 \\
\hline A4' & 432.80 & 312.40 & 2624.74 & 610.57 & 171,800 & 263.00 & 308.23 & 1084.10 & 36.16 & 3372.94 \\
\hline A4" & 432.36 & 312.17 & 2191.37 & 609.96 & 163,711 & 224.50 & 283.65 & 1043.24 & 30.15 & 3129.01 \\
\hline A5 & 432.8 & 356.33 & 2606.37 & 610.80 & 252,600 & 287.00 & 346.16 & 1043.35 & 33.42 & 3898.54 \\
\hline A5' & 414.37 & 338.92 & 2577.70 & 595.29 & 218,425 & 265.87 & 315.37 & 926.27 & 31.09 & 3823.41 \\
\hline A5” & 384.04 & 313.13 & 2126.87 & 541.54 & 110,978 & 216.75 & 299.06 & 908.84 & 29.43 & 3629.08 \\
\hline A6 & 445.96 & 360.63 & 2666.20 & 610.80 & 193,000 & 283.92 & 352.37 & 1086.19 & 39.99 & 3804.61 \\
\hline A6' & 432.80 & 338.87 & 2616.37 & 609.96 & 187,935 & 246.86 & 334.32 & 1084.10 & 36.23 & 3604.72 \\
\hline A6” & 432.35 & 304.83 & 2211.72 & 608.81 & 180,704 & 246.00 & 321.17 & 1040.06 & 35.98 & 3214.32 \\
\hline Average & 435.06 & 322.32 & 2515.03 & 596.45 & 185,894 & 249.95 & 309.32 & 1077.26 & 33.56 & 3530.32 \\
\hline
\end{tabular}


with an average of $3530.32 \mathrm{ppm}$.

\section{Conclusion}

Alkaline fusion method of black sand samples is a suitable method for the digestion of the samples due to eliminate of the matrix. ICP-MS is a good technique for its high efficiency of the detection of the trace elements. The concentration of the selected elements generally are decreased from the shore line backward the land area.

\section{REFERENCES}

[1] G. A. Dabbour, "Geological and Mineralogical Studies on Rutile in the Black Sand Deposits from the Egyptian Med. Coast," Ph.D. Thesis, Cairo University, Giza, 1980.

[2] G. A. Dabbour, "Estimation of the Economic Minerals Reserves in Rosetta Beach Sands," Egyptian Minerals, Vol. 7, 1995, pp. 1-6.

[3] Y. H. Dawod and M. H. Abd-Naby, "Mineral Chemistry of Monazite from the Black Sand Deposits, Northern Sinai, Egypt: A Provenance Perspective," Mineralogical Magazine, Vol. 71, No.4, 2007, pp. 389-406.

[4] M. A. El-Askary and O. E. Frihy, "Mineralogy of the Subsurface Sediments at Rosetta and Damietta Promontories," Egyptian Bulletin of the Institute of Oceanography and Fishery, Vol. 13, No. 2, 1987, pp. 111-120.

[5] A. F. A. El-Hadry, "Geologic and radiometric investigations on Abu Khashaba deposits, East Rosetta, Egypt," M.Sc. Thesis, Cairo University, Giza, 1988.

[6] M. I. M. Ibrahim, "Investigation of Some Physical Properties of Zircon and Rutile to Prepare High Purity Mineral Concentrates from Black Sand Deposits," M.Sc. Thesis, Mansoura University, Mansoura, 1995.

[7] M. N. El-Miligy and A. A. El-Azab, "Black Sand Project,” EGSA Annals, Paper No. 67, 1994, pp. 1-24.

[8] NMA, "International Report on Development of New Reserves for Black Sand Deposits," Abu Khashaba Rosetta, Egypt, 1988.

[9] S. R. Taylor and S. M. McLennan, "The Continental Crust Its Composition and Evolution: An Examination of the Geochemical Record Preserved in Sedimentary Rocks," Blackwell, Oxford, 1985.

[10] B. Anders, W. Junge, J. Knoth, W. Michaelis and J. R.
Vogt, "Nuclear Methods in Environmental Research," US-DOE, CONF-840408, 1984, p. 202.

[11] Standards Australia, “Australian Standard,” AAS 2912.2, 1994.

[12] G. Bumaa, G. Amar, S. V. Amosava and V. A. Potapov, Zhurnal Analiticheskoi Khimii, Vol. 47, 1992, p. 934.

[13] R. Boisvert, M. Bergeron and J. Tourcotte, "Re-Examination of the Determination of Palladium, Platinum and Rhodium in Rocks by Nickel Sulphide Fire Assay Followed by Graphite Furnace Atomic Absorption Measurements," Analytica Chimica Acta, Vol. 246, No. 2, 1991, pp. 365-373. doi:10.1016/S0003-2670(00)80974-5

[14] J. Tilch, M. Schuster and M. Schwarzer, "Determination of Palladium in Airborne Particulate Matter in a German City," Fresenius' Journal of Analytical Chemistry, Vol. 367 , No. 5, 2000, pp. 450-453. doi: $10.1007 / \mathrm{s} 002160000380$

[15] L. P. Kolosova, A. E. Aladyshkina, L. A. Ushinskaya and T. N. Kopylova, Zhurnal Analiticheskoi Khimii, Vol. 46, 1991, p. 1386.

[16] O. I. Artem, V. M. Stepanov, S. L. Terekhovich and B. M. Karater, Zhurnal Analiticheskoi Khimii, Vol. 48, 1993, p. 91.

[17] G. E. M. Hall and J. C. Pelchat, "Analysis of Geological Materials for Gold, Platinum and Palladium at Low ppb Levels by Fire Assay-ICP Mass Spectrometry," Chemical Geology, Vol. 115, No. 1-2, 1994, pp. 61-72. doi:10.1016/0009-2541(94)90145-7

[18] M. E. Farago, P. Kavanagh, R. Blanks, J. Kelly, et al., "Platinum Metal Concentrations in Urban Road Dust and Soil in the United Kingdom," Fresenius' Journal of Analytical Chemistry, Vol. 354, No. 5-6, 1996, pp. 660-663.

[19] E. K. Shibuya, J. E. S. Sarkis, J. Enzweiler, A. P. S. Jorge and A. M. G. Figueiredo, "Determination of Platinum Group Elements and Gold in Geological Materials Using an Ultraviolet Laser Ablation High-Resolution Inductively Coupled Plasma Mass Spectrometric Technique," Journal of Analytical Atomic Spectrometry, Vol. 13, No. 9, 1998, pp. 941-944. doi:10.1039/a801477i

[20] A. P. S. Jorge, J. Enzweiler, E. K. Shibuya, J. E. S. Sarkis and A. M. G. Figueiredo, "Platinum-Group Elements and Gold Determination in NiS Fire Assay Buttons by UV Laser Ablation ICP-MS," Geostandards Newsletter, Vol. 22, No. 1, 1998, pp. 47-55. doi:10.1111/j.1751-908X.1998.tb00544.x 